\title{
The Influence of Organizational Culture, Professional Commitment and Level of Religiosity to Ethical Judgement of the Auditor: Indonesia Evidence
}

\author{
RIO ARIEF YUDHISTIRA \\ HABIBUROCHMAN* \\ Universitas Airlangga
}

\begin{abstract}
The purpose of the research is to obtain empirical evidence about the impact of organizational culture, professional commitment and religiosity to ethical judgment of the auditor. The study was conducted by-administered questionnaire distribution model that applied to all the auditors who work in Public Accounting Firm (HOOD) in Surabaya. The sample in this research is 86 auditors from 18 Public Accounting Firm. Hypothesis testing was being done using PLS. The study found that organizational culture effect positively to the auditor's ethical judgment but facial took. While Auditors' commitment professional and the auditor's religiosity level effect positively significant to the auditor's ethical judgment
\end{abstract}

Keywords: Organizational Culture, Professional Commitment, Religiosity Level, The Auditor's Ethical Judgment

Intisari: Tujuan dari penelitian ini adalah untuk memperoleh bukti empiris tentang dampak budaya organisasi, komitmen profesional dan religiusitas terhadap penilaian etika auditor. Penelitian dilakukan dengan menggunakan model distribusi kuesioner yang diterapkan pada semua auditor yang bekerja di Kantor Akuntan Publik (HOOD) di Surabaya. Sampel dalam penelitian ini adalah 86 auditor dari 18 Kantor Akuntan Publik. Pengujian hipotesis sedang dilakukan menggunakan PLS. Studi ini menemukan bahwa budaya organisasi berpengaruh positif terhadap penilaian etis auditor tetapi pengambilan wajah. Meskipun komitmen profesional Auditor dan tingkat religiusitas auditor berpengaruh positif signifikan terhadap penilaian etis auditor

Kata kunci: Budaya Organisasi, Komitmen Profesional, Tingkat Religiusitas, Penilaian Etika Auditor

\footnotetext{
*Corresponding author : habib@feb.unair.ac.id
} 


\section{Introduction}

The auditor's profession will always be faced with a dilemma that results in an auditor being in conflicting choices. An auditor will experience a dilemma when there is no agreement or conflict with the client regarding some aspects and the purpose of an examination (Januarti, 2011). A dilemmatic situation may develop into an audit conflict when the auditor decides that contrary to independence and integrity. Some aspects of the function and purpose of the examination also often lead to differences of opinion between the auditor and the client (Hidayat and Handayani, 2010).

The existence of ethical problems faced by the auditor causes him to be assertive and precise, so in him will arise a correct consideration, namely ethical considerations. In the process of producing ethical considerations there are two factors that affect the auditor, namely external factors such as organizational culture code of ethics, culture and the working atmosphere while internal factors such as the characteristics of the individual, commitment, trust the experience and value - the value of the individual (Wawo et al., 2015).

According to Taurisa (2012), ethical considerations can be determined by the ethical culture of the organization. One of the external factors that affect the performance of the employees is organizational culture. The organizational culture is the values that develop in an organization value, where the values are used to direct the behavior of members of the organization (Soedjono, 2005). When a public accounting firm has a standard and rules that can form organizational culture, then the auditor can produce a quality decision. Professional commitment is an essential factor affects the behavior of an auditor when facing ethical issues in a conflict situation. Nasution and Ostermark (2012) stated that social pressure situation, whether the pressure of adherence to norms or customs, tends to affect the judgment of an auditor and the profession, and the rules inherent in it play a role in minimizing internal pressures.

Maryani and Ludigdo (2001) stated that the dominant factors affecting the attitudes and behavior of a person for the ethical attitude are religiosity. Religiosity is an individual factor which is attached to the individual because the religion which 
loaded the moral values is believed to be the philosophy of life that influences the formation of the attitude. With the awareness of the God-conscious, a professional accountant will always work with good and right with a sense of responsibility, not only to fellow human beings but also to the Lord.

Wawo et al. (2015) found that organizational culture through professional commitment affects the ethical judgment of the auditor in making decisions. While research from Purba and Zulaikha (2011) showed that organizational culture does not affect the ethical judgment when the auditor being idealistic so that the influence of organizational culture was set aside. The research did by Viceroy Lord, and DeZoort (2001) found that professional commitment has consideration impact of an auditor for ethical decision-making. But the study done by Nasution and Ostermark (2012) showed that professional commitment not significantly affected against the auditor considerations. Next, Walker et al. (2012) and Alter et al. (2013) found that the level of religiosity influences significantly for the ethical decision-making process of an auditor.

With the inconsistency on the results of earlier studies, this research tries to examine the influence of organizational culture as the external factors, the commitment of professional auditors and the level of religiosity of an auditor as internal factors of the ethical judgment of the auditor. This paper will continue the exposure of literature review, research method, results, and discussion, and conclusions.

\section{Theoretical Framework and Hypothesis Development}

\subsection{The theory of planned behavior}

Theory of planned behavior is a framework of conceptual thinking that aims to explain certain behavior determinant, besides the purpose and benefits of this theory is to predict and understand motivational influences the behavior of both the willingness of the individual itself and not the willingness of the individual. 
According to Ajzen (1991), the central factor of the behavior of the individual is that behavior was influenced by the motives of an individual (behavior intention) against the specific behavior. The main factor of an individual's behavior shown is the intention of an individual to display particular behavior. Park and Blenkinsopp (2009), said that the intention is assumed as motivational factors that affect the behavior. The intention is an indication of how hard someone tries or how many efforts to display a behavior. So, the harder intentions to a person to engage in a behavior, the greater personal tendency to perform such behavior (Buchan, 2005). Intention to behave influenced by three components namely (1) attitudes toward the behavior, (2) subjective norms and (3) perceived behavior control. Sequentially, behavioral belief produces positive or negative attitude toward an object, normative belief produces perceived social pressure or subjective norms, and control belief cause perceived behavioral control (Ajzen, 2002).

\subsection{Cognitive Moral Theory}

In cognitive moral theory that detriment by Kohlberg and Hersh (1977) share moral development into three level, namely pre-conventional level, conventional level and the level of post-conventional. According to the view of Kohlberg and Hersh (1977) from that three levels, someone must pass through the six levels in himself. According to Ponemon (1992), there are six levels in theory Kohlberg, in which each level of loading two stages of moral development. Level one and two from the moral development, called with pre-conventional, people make moral decisions based on the reward and punishment. At the level of three and four called Conventional, in this stage, a person is looking at the rules of the social order and the needs of each other. The level of the last five and six called PostConventional, where the good of the community has been inserted in the moral thinking. 


\subsection{Organizational Culture}

Organizational culture is a concept of the disclosure regarding the beliefs and values that are distributed widely in the organization to understand the atmosphere in the organization (Trevino et al. 2006). Organizational culture can affect how a person to achieve the desired objective (Lok and Crawford, 2003). The values and beliefs that developed or done in the organization are the basis of organizational culture. These values play an essential role in influencing the ethical behavior of the individual in the organization (Kreitner and Kinicki, 2001).

\subsection{Professional Auditor Commitment}

Smith and Hall (2008) define professional commitment as a love that formed by an individual on his profession. Professional commitment is defined as the intensity of identification and involvement of the individual with his profession. Specifically, high professional commitment should encourage the auditor to conduct following the public interest and away from the behavior that endangers the profession (Fig and J. P. Ferris, 1984). According to the Lord and DeZoort (2001), the auditor with high professional commitment will behave following the public interest and will not to damage the professionalism.

On the contrary, the auditor with low professional commitment will have the potential to behave unethically. According to research done by Wawo et al., (2015) professional commitment is an essential factor that affects auditor's behavior in the face of conflict situation regarding ethical issues. This shows with professional commitment are of course the ability of the auditor in considering the decision to produce any ethical decisions high.

\subsection{The auditor's level of religiosity}

In the framework of ethical behavior accountant, Maryani and Ludigdo (2001) describe some of the factors that could influence is religiosity, education, organizational, emotional skills and family environment. Among some of the factor is 
considered a factor of religiosity factors that most dominant influence ethical behavior an accountant. Religion as a system influences forming the attitude because he laid basics of the moral in the individual.

Religious activities not only occur when a person doing the ritual behavior or acts of worship, but also when doing other activities. Religiosity shows that there is a sense of God-conscious in an accountant, so that in the activities of his life always overwhelmed by theocentric dimension and no exception is also on the activity of professional work, Maryani and Ludigdo (2001).

\subsection{The Ethical Judgement of the Auditor}

Ethical judgment leads to the creation of consideration about the certain truth of the ethical actions such as what should be done (Ancient and Zulaikha, 2011). According to Hunt and Vitell (1986), ethical considerations is defined as a belief, against an alternative that most ethical convictions of some alternatives. From this definition in the ethical judgment required identification of various alternative, then select an option that most ethical. While according to the Rest (1986) ethical judgment as of the concept of psychology that describes a process of a person in determining the action according to which the right or wrong in the face of the situation ethical dilemma. The process of the stages of the ethical judgment includes the ethical thought of professional consideration such as professional competencies and understanding the ethics of his profession in troubleshooting issues that is ideal for dilemmatic ethical.

\subsection{The influence of organizational culture on the ethical considerations of the Auditor}

According to Douglas, et al. (2001), organizational culture affects the behavior of the auditor in considering the decisions, either directly (such as the training given by the organization and the rules applied in the organization) or indirect (such an atmosphere conducive organization working environment, then capable to forming 
personal values in an auditor). This is according to a dimension of the subjective norm in theory planned behavior which is the degree of how far a person will behave with following the view or the rules of other people someone will perform a behavior when he feels his personal rights to obey or rejects the view or the rules of other people. And in line with the dimension conventional on a cognitive moral theory that someone does something to attention the regulations that exist in the community or organization.

H1. Culture organization has a positive and significant impact on the ethical judgment of the auditor.

\subsection{The influence of professional commitment to the ethical judgment of the Auditor}

Jeffrey and Weatherholt (1996) said that the commitment of the profession is the intensity of identification and involvement of the individual with his profession. This identification requires some level of agreement between the individual with a purpose and values in the profession including the moral and ethical values. Jeffrey and Weatherholt (1996) also find that an accountant has a strong professional commitment and behavior more lead on obedience rules compared with an accountant have a low professional commitment. This shows that with professional commitment are the ability of the auditor in producing ethical decision is high. This is following the dimensions of attitude highly toward behavior in theory planned behavior, namely intention someone behaves as considering whether such behavior is beneficial or not. This is related to the professional commitment because in the professional commitment there are dimensions of continuance commitment of professionals who explain that someone does something because there is a need to get a good reward concerning the matter or moral.

H2. Auditor's professional commitment has a positive and significant impact on the ethical judgment of the auditor. 


\subsection{The influence of the level of religiosity of the ethical judgment of the Auditor}

According to research done by Walker et al. (2012) in general, religiosity affects ethical considerations, someone who has a high religiosity will consider all the behavior according to the teachings of religion. Because of the behavior of a person closely linked to the degree to which the understanding of religion. In line with the dimensions of perceived behavioral control on the theory planned behavior, namely individual will act when the individual feel has the ability or not in the displays such behavior. The underlying causes of this dimension are the section or believe someone will feel confident to do something when has the experiences of religious previously. Also, is also in line with the dimension of the post-conventional on cognitive moral theory namely someone behaves with think about the common good or public without the existence of the reasons that support a person to act.

H3. The level of religiosity of the auditor has a positive and significant impact on the ethical judgment of the auditor

\subsection{Theoretical Development Framework}

Picture 1

The Conceptual Framework of Research

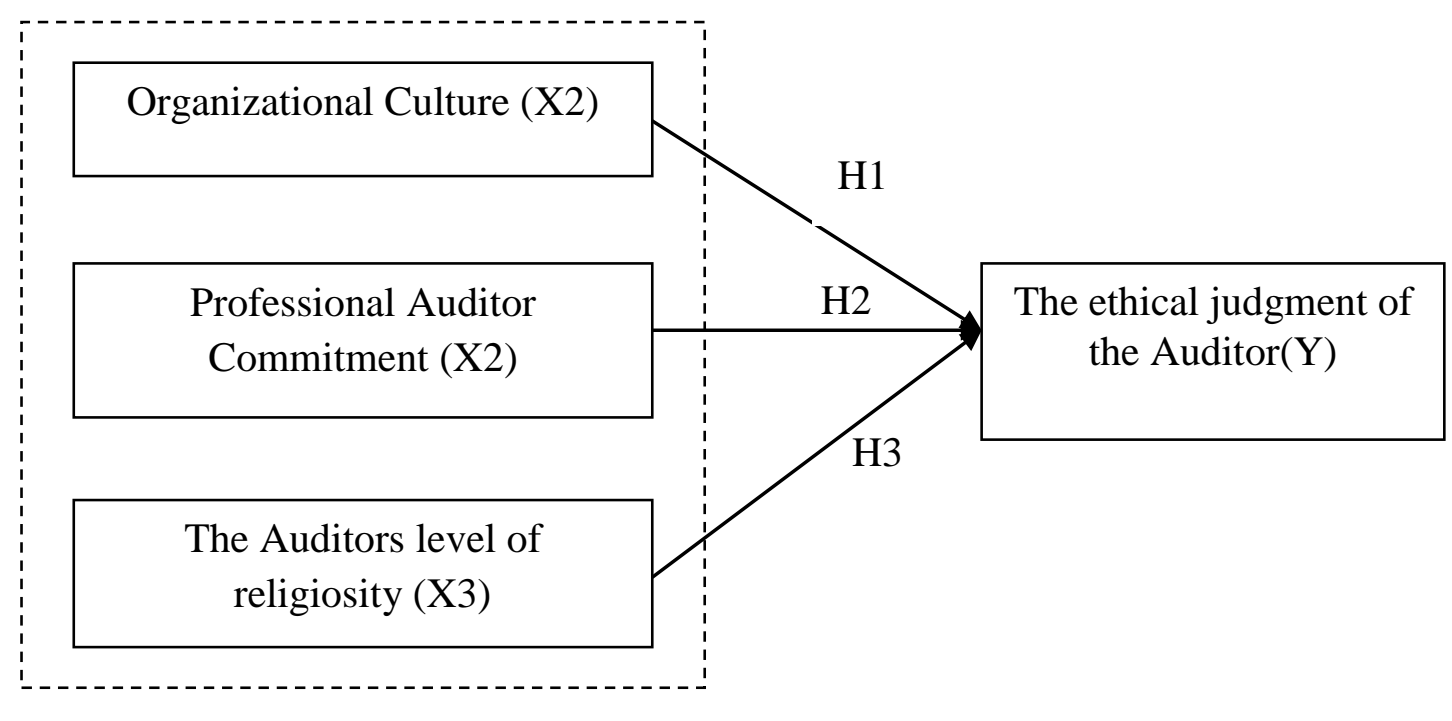




\section{Research Method}

The type of this research is quantitative research, with associative research methods and survey approach. Assumptions used in this research is in the form of the variables that can be measured and useful to explain the mutual relationship that began with the hypothesis and theories.

\subsection{Dependent variables/Tied}

In this research that become dependent variables is the ethical judgment of the auditor (Y). The ethical judgement variable measured by adopting (research Douglas, et al. 2001) by giving 5 examples of cases that illustrate an ethical problem that occurred in the public accountant, along with the action that is performed on the ethical issues and respondents asked to analyze each case and give opinion agree or disagree to the recommended actions on the case. The unit of measurement used to measure each statement in the ethical judgment variable is a Likert scale with the unit of points 1-5. (See Appendix 1)

\subsection{Independent variables or Free}

Now the free variable in this research is organizational culture (X1), the professional auditor's commitment (X2) and the level of religiosity of the auditor (X3).

\subsection{Organizational culture}

The measurement of the variables culture organization based on four dimensions developed by Hofstede (2011): (1) The Distance Power (2) the avoidance of uncertainty (3) Individualism-collectivism (4) Masculinity- femininity has been transformed both. In this questionnaire in each dimension represented by four questions indicator. The unit of measurement used to measure the organizational culture variables of the auditor is a Likert scale with the unit of points 1-5. (See Appendix 2) 


\subsection{Professional Auditor Commitment}

The professional auditor commitment variables measured with the indicator that has been developed by Meyers (1991) with three dimensional, namely (1) Affective Commitment Professional (2) Continuance Commitment Professional, and (3) Normative Commitment Professional. In this questionnaire ACP dimension represented by six questions indicator, $C C P$ dimension represented by the seven questions and $N C P$ represented by seven questions indicator. The units of measurement used to measure the variables of professional commitment are auditor Likert scale with the unit of points 1-5. (See Appendix 3).

\subsection{The Auditors Level of Religiosity}

The level of religiosity variables is measured with an instrument that has been developed by Stark and Glock (1968:14) with dimensions (1) ideological convictions (2) the practice of religion (3) religious experience (4) knowledge of religion (5) consequences. In this questionnaire, each dimension represented by three questions indicator measurement Units used to measure the variables the level of religiosity is a Likert scale with the unit of points 1-5. (See Appendix 4).

\subsection{The type of Data Source and Data Collection Method}

The Data in this research using primary data obtained from spread the questionnaire to 43 Public Accounting Firm (HOOD) in Surabaya. Respondents in this research are auditors who work in a public accounting firm in Surabaya with a position that consists of junior auditors, senior auditors, supervisor, managers, and partner. The primary data in this research in the form of personal characteristics of respondents, a name of respondents, workplace (HOOD), gender, levels of education, age, position, long worked (in HOOD) and questionnaire answers. 


\subsection{Data Analysis Model}

This research uses data analysis methods using software WarpPLS version 5.0. PLS (Partial This Square) and using outer model and inner model measurements. The outer model measurement used with the loading factor value in each indicator and used to test the validity of the change and the reliability of the instrument. According to Chin (1995) to research the early stages of the development of the scale outer loading values measurement of 0.50 to 0.60 considered enough. In this research used the value of the outer loading of 0.50. For inner model measurement that is used to test the relationship between the variables in the study used it said the value $\mathrm{R} 2$. It said the based $\mathrm{R} 2$ a model can be classified as strong ( $\leq$ $0.70)$, medium $(\leq 0.45)$ and weak $(\leq 0.25)$. While the relationship between the variables in the system that is built on research is calculated by using the value of the predictive relevance $(\mathrm{Q} 2)$ aims to assess the predictive validity of independent variables. The predictive validity of independent variables said good when have $\left(\mathrm{Q}^{2}\right)$ which is higher than zero.

This research also uses four sizes fit the model among others average path greatly enhanced(APC), average $R$-squared(ARS), average it said the $R$ squared (AARS) and average block variance inflation factor (AVIF). APC, ARS, AARS used to measure average values of path coefficient, $R$-squared and it said the $R$ squared produced in the model. The size of the third model fit is measured based on $p$ value that must be $\leq 0.05$. While AVIF used to test the problem of collinearity in the PLS model and the recommended value is $\leq 3.3$ (Ghozali and Latan, 2012:101-102).

In addition to this test, the validity in this research uses a comparison of the value of the square root of Average Variance Extracted (AVE) every change with a correlation between the change in the model. If the value of the root AVE every change is higher than the value of the correlation between the change with the change in the model and is said to have good validity discriminant value. The recommended value of the AVE should be greater 0.30 (Fornnel and Larcker, 1981 in Ghozali, 2006). While for testing the reliability, using composite reliability technique that 
measure can be evaluated with two kinds of the size of the internal consistency and Chronbach's Alpha (Ghozali, 2006). To view the reliability, whether or not a measure done through the coefficient reliability and when reliability coefficient greater than 0.60 , then the overall statement stated reliable.

This research on the hypothesis test is designed to assess the impact of the independent variables separately $(\mathrm{t})$ hypothesis test with the level of trust is $90 \%$, $95 \%$, or 99 percent so that the level of precision or limit of inaccuracies $(\alpha)=1-10 \%$. So:

1. If the value of $\mathrm{p}$-value $>\alpha$, then $H o$ failed to rejected and $H a$ rejected.

2. If the value of $\mathrm{p}$-value $<\alpha$, then the $H o$ was rejected, and $H a$ accepted.

\section{The results and discussion}

\subsection{Demographic description of respondents}

The subject in this research is a public accounting firm (HOOD) in Surabaya City listed in the directory of the year 2015-2016 HOOD, namely as many as 43-HOOD in Surabaya. After doing the spread of the questionnaire, from 43-HOOD in Surabaya, only 18-HOOD are willing to become the respondents of the survey with total 90 surveys scattered and as many as 86 questionnaires back (The response rate 95,5\%).

Based on the research that has been carried out against the auditor in Surabaya City HOOD, so it can be known characteristics of respondents based on (a) sexes, male and female $34,8965,11 \% \%$, (b) educational background: SMA 4.65\%; D3 6,97\%; S1 72.10 from Friday's levels\%; S2 16.28\% and S3 0\%, (c) long work: 0-1 years $9.3 \%$; $1-5$ years $63,96 \% ; 5-10$ years $23.25 \% ; 10-15$ years $2,32 \%$ and $>15$ years $1,17 \%$, (d) role: partner $1.16 \%$; managers $0 \%$, supervisor $0 \%$; senior auditors $18,60 \%$ and junior auditors $80,24 \%$, (e) age: $20-25$ years $67,45 \%$; $25-30$ years $18,60 \%$; $30-35$ years $1,98 \%$; $35-40$ years $1.16 \%$; $40-45$ years $2.33 \%$; $45-50$ years 0 percent and $>50$ years $1.16 \%$. 


\subsection{Model Analysis and Prove the Hypothesis}

\section{The estimation of Outer Model Measurement}

From the result of the estimation outer loading factor Iteration, 1 obtained some proxy which has a value higher than the 0.5 and lower than -0.5 . A proxy that has the value of the outer loading factor under 0.5 and higher than $-0,5$ assumed less worthy to be made the indicator that can reflect each of the variables in accordance (see Appendix 5).

To obtain optimal results, then proxy the proxy is unable to reflect the variables which have been determined will be eliminated and will be done by the calculation of the return on the value of the value of the outer loading. Based on the results of the outer loading factor and can be created a table of values outer loading factor for iteration deals. Table 1 below illustrates the reflective value of the indicators for each of the variables:

Table 1

The results of the estimation of Outer Loading Factor Iteration Deals

\begin{tabular}{|c|c|c|c|}
\hline The variables & $\begin{array}{c}\text { The } \\
\text { indicator }\end{array}$ & $\begin{array}{c}\text { The value of } \\
\text { the Outer } \\
\text { Loading }\end{array}$ & Conclusion \\
\hline \multirow{3}{*}{$\begin{array}{l}\text { Organizational } \\
\text { culture }\end{array}$} & MFK3 & 0.620 & Significant \\
\hline & IK1 & 0.638 & Significant \\
\hline & $\mathrm{JK} 2$ & 0.817 & Significant \\
\hline \multirow{3}{*}{$\begin{array}{l}\text { Professional } \\
\text { Commitment }\end{array}$} & AC6 & 0.799 & Significant \\
\hline & $\mathrm{CC} 1$ & -0.668 & Significant \\
\hline & CC6 & 0.799 & Significant \\
\hline \multirow{4}{*}{$\begin{array}{l}\text { The level of } \\
\text { religiosity }\end{array}$} & PA1 & 0.684 & Significant \\
\hline & PR1 & 0.713 & Significant \\
\hline & PR2 & 0.630 & Significant \\
\hline & PR3 & 0.784 & Significant \\
\hline $\begin{array}{l}\text { The ethical } \\
\text { judgment }\end{array}$ & $\mathrm{PE}$ & 1000 & Significant \\
\hline
\end{tabular}


From the Table 1 above all the proxy has the value of the outer loading factor greater than 0.5 or lower than $-0,5$ from new iteration results. It could be concluded that the whole proxy has qualified to become as indicators that can reflect each variable the related and the second iteration is the iteration to determine the indicators used as reflective indicators from each of the variables.

\subsection{Validity and reliability of the variables test}

The results of the validity of the testing in the laboratory of this show that all the variables have the value of the discriminant validity above 0.30 (see Appendix 6). So it can be concluded that all the variables are valid and can provide the confidence. While reliability tests showed that all variables have the value of composite reliability more significant than 0.70 (see Appendix 7). From the results, it can be concluded that all of the variables in the research are reliable and reliable to be used in the further analysis test.

\subsection{Fit Model test}

Based on the test results showed that the Fit Model in this research stated fit with APC, ARS, and AARS have a p-value less than 0.05. While the value of AVIF $<3.3$ shows that there are no multicollinearity problems between the indicator and the variables used (see Appendix 8).

\subsection{The estimation of the Inner Model Measurement}

The value of $R$-square it said ( $R 2$ it said the endogenous variable is the ethical judgment variable is $0,498(49,8 \%)$. This shows that the ethical judgment variables can be explained by $49,8 \%$ by cultural variables organization, professional commitment and the level of religiosity. The remaining USD 50.2\% variables ethical considerations auditors influenced by variables - variables which are not tested in this research.

\subsection{The results of statistics and discussion of Research test}

The results from the calculation of the t-test statistics using the model of partial 
this square with the rank of the significance of 5 percent in this research can be summarized in table 2 below:

Table 2

The results of the t-Test statistics

\begin{tabular}{|c|c|c|c|}
\hline $\begin{array}{c}\text { The relationship between the } \\
\text { variables }\end{array}$ & $\begin{array}{c}\text { Original } \\
\text { Sample (O) }\end{array}$ & $\begin{array}{c}\mathbf{P} \\
\text { Values }\end{array}$ & Conclusion \\
\hline $\begin{array}{l}\text { Organizational Culture-> Ethical } \\
\text { Judgement }\end{array}$ & 0.072 & 0.249 & $\begin{array}{l}\text { Positive, not } \\
\text { significant; } \mathrm{H} 1 \\
\text { rejected }\end{array}$ \\
\hline $\begin{array}{l}\text { Professional commitments> } \\
\text { Ethical Judgement }\end{array}$ & 0.337 & $<0.001$ & $\begin{array}{l}\text { Significant positive; } \\
\text { H2 accepted }\end{array}$ \\
\hline $\begin{array}{l}\text { The level of religiosity of the } \\
\text { Auditor-> ethical judgment }\end{array}$ & 0.791 & $<0.001$ & $\begin{array}{l}\text { Significant positive; } \\
\text { H3 accepted }\end{array}$ \\
\hline
\end{tabular}

Source: Processed Data (2016)

\subsection{The discussion}

\section{The influence of organizational culture on ethical considerations the Auditor}

The results of this research showed that the variables organizational culture have positive but not significant for the ethical judgment of the auditor, so $\mathrm{H} 1$ rejected. This shows that organizational culture is good in the HOOD does not guarantee whether the auditor can take a decision through the ethical judgment, but ethical judgment of the auditors is likely to be more influenced by individual factors or personal than external factors or factors situational answer.

In this research showed that although the auditors who work in a public accounting firm to maintain harmony between colleagues. This does not affect the consideration of the auditor in making decisions. Maintain harmony between colleagues is not the things that affect the attention of the person in considering a decision. Because when one of the auditors determine a decision to consider is the findings on the financial report and it is not about a relationship with auditor colleagues. The Auditor who can keep himself from the conflict that is outside of work also does not affect the consideration of the auditor in the ethical decisions. This is due to disputes that occur outside of work has nothing to do with the existing 
activities in the work when the auditor considers a decision that considered are the problems related to the scope of work as its credibility as the auditor, HOOD good name where he worked and trust the client.

Although organizational culture needs to be owned by every public accountant, when an auditor working in the HOOD does not have a strong professional commitment and best anything culture of the organization that applied in the hood does not affect the auditor in considering the ethical in taking the decision. Following the theory of planned behavior described by Ajzen (1991) that attention someone to behave influenced by Subjective Norm which is the extent to which a person has the motivation to follow the views of the behavior that will be done (Normative Belief). If an auditor feels that is his rights to determine what he would do and not determined by other people around him, then he will ignore the views of people about the behavior that will be done.

This is in line with the ancient research and Zulaikha (2011) which shows that organizational culture affects the ethical judgment but not significant because when the auditor being idealistic and the influence of organizational culture was set aside. Also, the research was done by Mingzhi (2006) also find that organizational culture affects the ethical judgment of the auditor but not significant. But the results of this research are different with the research done by Wawo, et al. (2015) find that organizational culture affects the ethical judgment of the auditor.

\section{The influence of professional commitment to Auditor Auditor Ethical}

\section{Considerations}

Professional commitment variables affect auditor significant for ethical judgment of the auditor, so $\mathrm{H} 2$ accepted. It can be concluded that the commitment of professional auditors is one of the essential factors for the auditor to consider an ethical decision. In this research one of the auditors that love for his profession will have a sense of ownership over the HOOS where he worked and affect auditors in considering a decision. This is in line with the dimension of the Affective Commitment Professional on the theory of professional commitment developed by Meyer and 
Allen (1991) that the desire of a person to do something to the achievement of the goal of the organization caused by the individual have emotional ties to the organization. So, an auditor that has a sense of ownership over the hood will be careful - the heart in considering a decision because of her love of the organization or the HOOD.

Also, in this research also found that one of the auditors that would receive anything that was commissioned by the HOOD, corresponding consciousness in himself to do the work with the best and give everything to survive in the HOOD and help the HOOD to successfully achieve its purpose. This is in line with the dimension of the normative Commitment Professional on the theory of professional commitment developed by Meyer and Allen (1991), that intention someone to remain a member in an organization caused by his realization itself.

This result supports the research carried out by Wawo et al. (2015), professional commitment is one of the factors that affect the behavior of the auditor in determining the ethical considerations. One of the auditors who have professional commitment can assess something ethical or unethical, so that capable to avoid actions that contradict the rule. Then the result is also in line with the research done by the Lord and DeZoort (2001), the auditor with high professional commitment will behave following the public interest and will not damage his professionalism. On the contrary, the auditor with low professional commitment will have the potential to behave uterine. But the results of this research are different with the research done by Nasution and Ostermark (2012) who find that the professional commitment does not affect the auditor considerations.

The influence of the level of religiosity of the Auditor against the ethical judgment of the Auditor

The level of religiosity has the highest value than other independent variables. It can be concluded that the level of religiosity of the auditor is one of the factors that are very important for the auditor to consider ethical decisions. Religiosity in redefines as the extent to which the individual is committed to religion and the teachings - the teachings in it, including a commitment which religion against the attitudes and behavior of the individual. In this study found that one of the auditors will be able to 
consider ethical decisions when the corresponding initiate all their activity to pray according to the religion and the confidence of each. With the corresponding invocation hope that given the smooth by The One True God in each of their activity that arises a sense of comfort and tranquility in work. One of the auditors that have tranquility will be easy to assess the things that are not ethical and unethical to be done.

Also, an auditor will feel calmer and able to work with better when they have to do the ritual of worship according to the religion that believed. So, the impact of the ritual of worship can create an auditor to assess the things that are not ethical and ethical and will feel can work better. One of the auditors that diligent pray and perform acts of worship of course due to feeling all the activities that he did supervise by God the Almighty. Therefore, the attitude feel supervised by the One True God is also able to avoid an auditor to act in unethical, when new only arise an intention to act unethically then one of the auditors will consider the action because he felt supervised by God the Almighty.

The reason someone wants to run the command and away from the ban on religious teachings are for the corresponding have religious experience as feel helped and simplicity of God the Almighty. So that a person is attempting to act according to what is taught in the religion and avoid the restrictions apply to get help back from God the Almighty. Therefore, the attitude believes the help of God affects the auditor in considering a decision. This is in line with the dimensions of religious experience on the theory of religiosity developed by Stark and Glock (1968) and the dimensions of perceived behavioral control on the cognitive moral theory developed by Kohlberg and Hersh (1977) that one acts because they have done it before and feel able to do so. These results also support research by Hutahahean and Hasnawati (2015) that shows someone's religious belief plays an essential role in the decision-making process. This is because of the ethical values and personal standards that are often associated with the background of the religion of a person the meaning is that every religion embraced by someone has rules - rules that must be kept by the adherents of the religion. 
This result is also in line with the research done by Alter et al. (2013) and Walker et al. (2012) that in general religiosity affect ethical judgment of the auditor, someone who has a high religiosity will consider all the behavior according to the teachings of his religion because of the behavior of a person closely linked to the degree to which the understanding of religion.

\section{Conclusions, Limitations and Implications}

Based on the results of the test analysis that has been done on the variables which are examined, the conclusions that can be taken from this research is a variable culture organization have positive but not significant for ethical considerations while auditor professional commitment variable and the level of religiosity auditors' significant effect against the ethical judgment of the auditor.

Now some limitations in the preparation of this research among others, first, some indicators are not valid in Organizational Culture variables, professional commitment and the level of religiosity that should be replaced with indicators that more valid. Second, the number of respondents who reigned as a senior auditor were inferior namely 16 people or $18,60 \%$ so that the attitudes and behavior of senior auditor during work in Public accounting firm less can be examined more in. Third, not all the HOOD restores the questionnaire, only 18-HOOD that will fill or restore the survey to the researchers from the total 43 HOOD in Surabaya. By percentage according to the number of HOOD, only 41,86\% HOOD that will fill the survey or restore the study so that the power of the test-him less powerful.

\section{References}

Ajzen, I. (1991). The Theory of Planned Behavior. Organizational Behavior and Human Decision Patterns, 179-211.

Ajzen, I. (2002). Perceived Behavioral Control, Self-Efficacy, Locus of Control and The Theory of Planned Behavior. Journal of Applied Social Psychology, 665-683. 
Alteer, A. M., Yahya SB., Haron MH., (2013). Religiosity and Auditors' Ethical Sensitivity at different levels of Ethical Climate: A Conceptual Link. The American Journal of Economics, 3(5C): 119-124. doi:DOI: 10.5923/c.community economics.201301.20

Buchan, H. (2005). The ethical Decision making In The Public Accounting Profession: An Extension of Ajzen's Theory Of Planned Behavior. The Journal of Business Ethics, 165181.

Chin, W.W. (1995). Partial This Square is to U.S. Principal Component LISREL Analysis is too simple Factor Analysis. Technology Studies, 2:315-319.

Douglas, P. C., Davidson, R., \& Schwartz. (2001). The Effect of Organizational Culture and Ethical Orientation on Accountants' Ethical Judgments. The Journal of Business Ethics, 101-121.

Fig N., \& J. P. Ferris, K. (1984). A Reexamination of Accountant Organizational- Professional Conflict. The Accounting Review, vol.LIX, no.1, January, 1-15.

Ghozali, I. (2006). Multivariate Analysis application with SPSS Program. Semarang: Agency Publisher Undip.

Ghozali, I. \& Latan, H. (2012). Partial This Square Concept, methods, and applications using WarpPLS4.0 Program. Semarang: Diponegoro University.

Hidayat, W., \& Handayani, S. (2010). The role of the individual factors and ethical considerations against the Auditor behavior in situations of conflict on the Environment Audit Inspektorat Jenderal Southeast Sulawesi. The Journal of economic partners and Business Management, Vol.1, No. 1 April 2010, 83-112.

Hofstede, G. (2011). Dimensionalizing Cultures: The Hofstede Model. Online Readings in Psychology and Culture, Vol 2.

Hunt, S. D., \& Vitell, S. (1986). A General Theory of Marketing Ethics (Vol. 6). The Journal of Macromarketing.

Hutahahean, M. B., \& Hasnawati. (2015). The influence of gender, religiosity and learning achievements against the ethical behavior of Future Accountant (Study On Accounting Students Private Universities in the region of DKI Jakarta). E-Journal Accounting Trisakti, 2(1), 49-66.

Januarti, I. (2011). Analysis of the influence of the experience of the Auditor, professional commitment, Ethical Orientation and ethical values of the Organization of the perception and ethical considerations (Auditor of the Audit Board of Indonesia). Accounting National Symposium XIV, 1-37.

Jeffrey, C., \& Weatherholt, N. (1996). The ethical Development, Professional Commitment, 
And Rule Observance Attitudes: A Study Case of CPAs And Corporate Accountants. Behavioral Research in Accounting, Vol 8.

Kohlberg, L., \& Hersh, R. (1977). Moral Development: A Review of The Theory. Theory into Practice, 53-59.

Kreitner, R., \& Kinicki, A. (2001). Organizational Behavior, 5th Edition. Boston: Irwin McGraw-Hill.

Lok, P., \& Crawford, J. (2003). The Effect of Organisational Culture and Leadership Style on Job Satisfaction and Organizational Commitment A Cross-National Comparison. Journal of Management Development, 321-328.

Lord, A. T., \& DeZoort, F. T. (2001). The Impact of Commitment and Moral Reasoning on Auditors' Responses to Social Influence Pressure. Accounting Organization and Society, $26,215-235$.

Maryani, T., \& Ludigdo, U. (2001). A survey of that Influenced the attitude and ethical behavior an accountant. The Journal of the theme, 2(1), 49-62.

Meyer, J. P., \& Allen, N. A. (1991). A Three-Component Conceptualization Model of Organizational Commitment. Human Resource Management Review. Vol. 1, Number 1, 61-89

Mingzhi, L. (2006). The Ethical patterns of Professional Decision-Making Auditors in The People's Republic of China (Master's thesis, Lingnan University in Hong Kong). Retrieved from http://dx.doi.org/10.14793/acct_etd.9

Nasution, D, \& Ostermark, R. (2012). The Impact of Social Pressures, Locus of control and professional commitment on. Asian Review of Accounting, 20(2), 163 - 178. Retrieved June 3, 2016.

Park, H., \& Blenkinsopp, J. (2009). U.s. Whistleblowing Planned Behavior - A Survey of South Korean Police officials. The Journal of Business Ethics, 545-556.

Ponemon, L. A. (1992). The Auditor Underreporting Of Time And Moral Reasoning: An Experimental Lab Study. Contemporary Accounting Research, 171-189.

Ancient, S. V.\& Zulaikha (2011). The influence of ethical orientation toward the ethical judgment of the Auditor with the ethical culture of the organization as a Moderating variable. Economics Faculty of Diponegoro University, 1-29.

Rest, J. R. (1986). Moral development: Advances in research and theory. New York: Prager.

Smith, D, \& Hall, M. (2008). An Empirical Examination Of A three-Component Model Of Professional Commitment Among Public Accountants. Behavioral Research In Accounting, 75-92. 
Soedjono. (2005). The influence of organizational culture to the performance of the Organization (Vol.7). Surabaya: Journal of management and entrepreneurship Petra University.

Stark, R., \& Glock, C. Y. (1968). American Piety: The Nature of Religious Commitment. Berkeley: University of California Press.

Taurisa, C. M. (2012). Analysis of the influence of organizational culture and Customer Satisfaction (Vol. 19). Semarang: The Journal of Business and Economy (JBE).

Trevino, L. K., Weaver, G. R., \& Reynolds, S. J. (2006). Behavioral Ethics in financial: A Review. The Journal of Management, 951-990.

Walker, A. G., Smither, J., \& DeBode, J. (2012). The Effects of religiosity on Ethical Judgments. The Journal of Business Ethics, 437-452.

Wawo, A. B., N. A., \& S. N. (2015). The influence of organizational culture, ethical awareness and experience to ethical judgments auditors through professional commitment (Study at Inspectorate Sub-Province of include Bombana). The International Journal of Engineering and Science (IJES), Volume 4, 15 - 25. 